University of Nebraska - Lincoln

DigitalCommons@University of Nebraska - Lincoln

USDA National Wildlife Research Center - Staff Publications
U.S. Department of Agriculture: Animal and Plant Health Inspection Service

June 2001

\title{
INFREQUENT COWBIRD PARASITISM ON COMMON GRACKLES REVISITED: NEW RECORDS FROM THE NORTHERN GREAT PLAINS
}

Brian D. Peer

Lawrence Univ., Appleton, WI

H. Jeffrey Homan

USDA/National Wildlife Research Center/Great Plains Field Station

Spencer G. Sealy

Univ. of Manitoba, Winnipeg, MB, Canada

Follow this and additional works at: https://digitalcommons.unl.edu/icwdm_usdanwrc

Part of the Environmental Sciences Commons

Peer, Brian D.; Homan, H. Jeffrey; and Sealy, Spencer G., "INFREQUENT COWBIRD PARASITISM ON COMMON GRACKLES REVISITED: NEW RECORDS FROM THE NORTHERN GREAT PLAINS" (2001). USDA National Wildlife Research Center - Staff Publications. 535.

https://digitalcommons.unl.edu/icwdm_usdanwrc/535

This Article is brought to you for free and open access by the U.S. Department of Agriculture: Animal and Plant Health Inspection Service at DigitalCommons@University of Nebraska - Lincoln. It has been accepted for inclusion in USDA National Wildlife Research Center - Staff Publications by an authorized administrator of DigitalCommons@University of Nebraska - Lincoln. 


\title{
INFREQUENT COWBIRD PARASITISM ON COMMON GRACKLES REVISITED: NEW RECORDS FROM THE NORTHERN GREAT PLAINS
}

\author{
BRIAN D. PEER,,${ }^{1,4}$ H. JEFFREY HOMAN,${ }^{2}$ AND SPENCER G. SEALY ${ }^{3}$
}

\begin{abstract}
We report nine new records of Brown-headed Cowbird (Molothrus ater) parasitism on the Common Grackle (Quiscalus quiscula): six from Benson County, North Dakota, and three from Delta Marsh, Manitoba. These observations represent $30 \%$ of the total number of records of parasitism on this host. Parasitism frequencies were $0.8 \%$ of 727 nests in North Dakota, and $4.0 \%$ of 75 nests in Manitoba. The data from Manitoba, combined with previous data from this location (Neudorf and Sealy 1994), yields a parasitism frequency of $3.4 \%$ of 119 nests examined. These parasitism frequencies are the highest recorded for the Common Grackle. Received 2 June 2000, accepted 2 February 2001.
\end{abstract}

Survival of obligate avian brood parasites demands that they lay their eggs in nests of hosts that are capable of successfully rearing the parasite's young. Host selection by the parasitic Brown-headed Cowbird (Molothrus ater), however, is often enigmatic. Frequencies of cowbird parasitism vary geographically for appropriate hosts (Robinson et al. 1995, Peer et al. 2000), and hosts that are unsuitable because their nests are inaccessible or they are incapable of rearing brood parasites sometimes are parasitized more often than suitable hosts (Rothstein 1976, Ortega and Cruz 1991, Kozlovic et al. 1996, Peer and Bollinger 1997a).

Among the rarely parasitized but suitable cowbird hosts is the Common Grackle (Quiscalus quiscula). The Common Grackle previously has been reported parasitized by the Brown-headed Cowbird only 21 times, despite ranging widely across North America in the cowbird's range (Peer and Bollinger 1997b; see also Fleischer 1986). Friedmann et al. (1977) commented on the curious lack of cowbird parasitism on Common Grackles, which prompted the experiments by Peer and Bollinger (1997a) that demonstrated that despite their large size, Common Grackles are

\footnotetext{
${ }^{1}$ Dept. of Biology, Lawrence Univ., Appleton, WI 54912.

${ }^{2}$ USDA/National Wildlife Research Center/Great Plains Field Station, 2110 Miriam Circle, Suite B, Bismarck, ND 58501.

${ }^{3}$ Dept. of Zoology, Univ. of Manitoba, Winnipeg, MB R3T 2N2, Canada.

${ }^{4}$ Corresponding author; E-mail: brian.d.peer@ lawrence.edu
}

suitable hosts. Peer and Bollinger found that $20 \%$ of cross-fostered cowbird nestlings fledged from grackle nests. Two noteworthy findings from their study were that grackles responded more aggressively to cowbird models than to control models, suggesting some recognition of cowbirds as a threat, and that grackles demonstrated a low level of egg ejection behavior (see also Rothstein 1975, Sealy et al. 1998). Peer and Bollinger (1997a) argued that cowbirds avoid grackles as potential hosts because historically grackles may have rejected most cowbird eggs from their nests. In the absence of parasitism, Common Grackles may have lost the advantages of rejection behavior and increased the risk of ejecting their own eggs due to their highly variable appearance within clutches (Peer and Bollinger 1997a, Peer 1998). In support of this, Peer (1998) found that Common Grackles demonstrated the lowest level of egg rejection among the rarely, if ever, parasitized members of Quiscalus, and the highest level of intraclutch variation in egg appearance. Here we report nine new records of parasitism on the Common Grackle from the northern Great Plains and review this grackle's status as a host of the Brown-headed Cowbird.

\section{METHODS}

Common Grackle nests were observed from 1989 to 1990 in Benson County, North Dakota $\left(48^{\circ} 00^{\prime} \mathrm{N}, 99^{\circ}\right.$ $20^{\prime}$ W), and from 1992 to 1995 at Delta Marsh, Manitoba $\left(50^{\circ} 11^{\prime} \mathrm{N}, 98^{\circ} 19^{\prime} \mathrm{W}\right)$. Benson County is typified by croplands interspersed with numerous wetlands and shelterbelts. Most grackle nests in Benson County were located in shelterbelts and were observed only once as part of a study of nest-site selection (Homan et al. 1996). The Delta Marsh study area is located on 
the southern end of Lake Manitoba (see MacKenzie 1982 for details). Grackle nests were found at the edge of the marsh and in and along ditches south of the forested dune ridge. Nests were typically placed in cattails (Typha spp.) and phragmites (Phragmites communis), though some were in willows (Salix spp.). Unlike the North Dakota portion of our study, the focus of the Manitoba study was on cowbird parasitism. Nests were monitored daily through at least clutch completion for evidence of cowbird parasitism. Most nests $(77 \%)$ in Manitoba were also experimentally parasitized with model cowbird eggs. All potential habitat at both the Benson County and Delta Marsh sites was searched thoroughly for grackle nests. Nests in North Dakota were checked only for the presence of cowbird eggs, not nestlings; thus nests that contained only nestlings were excluded from the data set. We defined a grackle colony as $\geq$ three nests within $10 \mathrm{~m}$ of one another (Peer and Bollinger 1997a).

\section{RESULTS AND DISCUSSION}

Six parasitism events were recorded at 727 nests $(0.82 \%)$ in North Dakota. One nest found on 6 June 1989 contained two grackle eggs and one cowbird egg. Five parasitized nests were found in 1990. On 29 and 31 May, each of two nests held three host eggs and one cowbird egg, and also on 31 May, a second nest contained three host eggs and two cowbird eggs. Two more nests were found within the same colony on 7 June: one with one host egg and a cowbird egg, and the other with one host egg and two cowbird eggs. Five of the six parasitized nests were located in colonies. There was no significant difference in the parasitism frequency for the two years (1/161 nests in 1989, 5/566 in 1990; Fisher exact test, $P>0.99)$. We may have underestimated the parasitism frequency in North Dakota because no attempt was made to detect cowbird nestlings, and these nests were observed only once, so cowbird eggs may have been rejected by grackles before nests were observed or nests may have been parasitized later. Although possible, it probably did not influence our results significantly because grackles reject cowbird eggs infrequently (12-17\%; Rothstein 1975, Peer and Bollinger 1997a).

In Manitoba, three of 17 unmanipulated nests were parasitized, compared with 0 of 58 manipulated nests (Fisher exact test, $P=$ 0.01 ). Two nests found in the same colony on 24 and 25 May 1992 each contained one cowbird egg and one host egg. Both cowbird eggs were removed for other experiments. The
TABLE 1. Known records of Brown-headed Cowbird parasitism on Common Grackles.

\begin{tabular}{lll}
\hline Location & $\begin{array}{c}\text { Parasitism } \\
\text { events } \\
\text { (total number } \\
\text { of nests) }\end{array}$ & \multicolumn{1}{c}{ References } \\
\hline Illinois & $4(?)$ & Friedmann (1963) \\
Iowa & $1(46)$ & Lowther (1991) \\
Kansas & $1(23)$ & Fleischer (1986) \\
Manitoba & $1(44)$ & Neudorf and Sealy (1994) \\
Maryland & $3(75)$ & This study \\
Minnesota & $1(?)$ & Friedmann et al. (1977) \\
Nebraska & $2(?)$ & Friedmann and Kiff (1985) \\
New York & $1(?)$ & Friedmann et al. (1977) \\
North Dakota & $2(?)$ & Friedmann et al. (1977) \\
& $1(?)$ & Friedmann (1963) \\
Ontario & $6(727)$ & This study \\
Saskatchewan & $4(2091)^{1}$ & Peck and James (1987) \\
Texas & $2(?)$ & Friedmann and Kiff (1985) \\
Total & $1(?)$ & Friedmann (1963) \\
\hline
\end{tabular}

${ }^{1}$ Friedmann et al. (1977) reported a parasitized nest in Ontario from the Ontario Nest Record Program. We assume this record is among those reported by Peck and James (1987), hence, we did not include Friedmann's reference to this record in this list.

third parasitized nest was found on 22 May 1995 containing five host eggs and one cowbird egg. The cowbird egg was subsequently depredated. All of the parasitized nests in Manitoba were in colonies; thus eight of the nine parasitized nests from our study were located in colonies. The data from Manitoba, combined with previous data from this site (Neudorf and Sealy 1994), yields a parasitism frequency of 3.4\% on 119 nests. Experimental addition of cowbird eggs to grackle nests in Manitoba may have affected natural cowbird behavior. Similar to the findings of Ortega and coworkers (1994), nests that were experimentally parasitized were naturally parasitized less frequently than unmanipulated nests. Therefore our experiments may have made cowbirds less inclined to parasitize these nests. Nevertheless, these data still represent the highest parasitism frequencies reported for this host.

The nine new cases of cowbird parasitism represent $30 \%$ of the total parasitism events recorded for the Common Grackle. In addition to those listed in Peer and Bollinger's review (1997b), and one from Fleischer (1986), these bring the total number of records of parasitism to 30 (Table 1). Despite the relatively large number of parasitized nests, the parasitism frequencies were still low, 3.4\% at Delta Marsh being the highest. The low frequency of parasitism is also evident from the following data sets: 0 of 1795 nests (Friedmann et 
al. 1977), 0 of 371 nests (Goertz 1977), 4 of 2091 nests (Peck and James 1987), and 0 of 401 nests (Peer and Bollinger 1997a). Hence, the Common Grackle is a very rare host of the cowbird, perhaps the least frequently used of all suitable hosts.

Common Grackles are among the earliest nesting passerines in North America, with the peak of clutch initiation occurring in mid- to late April in the Midwest (Peer and Bollinger 1997a, b). Peer and Bollinger (1997a) found that $89 \%$ of grackle nests in Illinois were beyond the point of successful parasitism when cowbirds began laying, which suggests that the mismatch of grackle and cowbird breeding seasons may contribute to the low levels of parasitism there. However, Peer and Bollinger (1997a) noted that despite this, more grackle nests were available for parasitism than all other host species in the community except one, indicating that grackle nests were avoided. In Manitoba, grackles arrive in late March through April, and although the first clutches are initiated in early May, most laying occurs during the latter half of May (SGS, pers. obs.). Cowbirds begin arriving about the end of the first week of May and begin laying shortly thereafter (SGS, pers. obs.). Thus, the more closely aligned breeding seasons of the two species may contribute to the higher parasitism frequencies recorded in the northern Great Plains.

Cowbirds may parasitize Common Grackles early in the cowbird's laying season in Manitoba because few alternate hosts nest that early. Indeed, a grackle nest parasitized on 15 May 1991 was the earliest record of parasitism recorded on any species at Delta Marsh in nearly $30 \mathrm{yr}$ of observations (Neudorf and Sealy 1994; SGS, pers. obs.). Most known observations of parasitism on the Common Grackle $(77 \%)$ are from the Great Plains (Table 1) and perhaps not coincidentally cowbird population densities are highest there (Price et al. 1995, Ortega 1998). Greater densities of cowbirds in the northern Great Plains may lead to higher frequencies of parasitism on rarely used hosts such as the Common Grackle. In addition to the more closely matched breeding seasons of cowbirds and grackles, this may explain the relatively high frequencies of parasitism we observed for this host.

\section{ACKNOWLEDGMENTS}

The North Dakota data were collected with the support of the USDA, NWRC, Ft. Collins, CO, and the Department of Zoology, North Dakota State University, Fargo, ND. P. N. Hébert, J. C. Lorenzana, C. M. McLaren, and D. L. Neudorf provided field assistance at Delta Marsh. The University of Manitoba Field Station provided living accommodations at Delta Marsh, and funding for this portion of the study was provided by a Natural Sciences and Engineering Research Council of Canada grant to SGS.

\section{LITERATURE CITED}

FleischeR, R. C. 1986. Brood parasitism by Brownheaded Cowbirds in a simple host community in eastern Kansas. Kansas Ornithol. Soc. Bull. 37: 21-29.

FriedmanN, H. 1963. Host relations of the parasitic cowbirds. U.S. Natl. Mus. Bull. No. 233.

Friedmann, H. AND L. F. KIFF. 1985. The parasitic cowbirds and their hosts. West. Found. Vert. Zool. 2:225-304.

Friedmann, H., L. F. Kiff, And S. I. Rothstein. 1977. A further contribution to knowledge of the host relations of the parasitic cowbirds. Smithson. Contrib. Zool. No. 235.

GoertZ, J. W. 1977. Additional records of Brownheaded Cowbird nest parasitism in Louisiana. Auk 94:386-389.

Homan, H. J., G. M. Linz, W. J. Bleier, And R. B. CARLSON. 1996. Colony-site and nest-site use by Common Grackles in North Dakota. Wilson Bull. 108:104-114.

Kozlovic, D. R., R. W. Knapton, and J. C. Barlow. 1996. Unsuitability of the House Finch as a host of the Brown-headed Cowbird. Condor 98:253258.

Lowther, P. E. 1991. Catalog of Brown-headed Cowbird hosts from Iowa-an update. Iowa Bird Life 61:33-39.

MACKENZIE, D. I. 1982. The dune-ridge forest, Delta Marsh, Manitoba: overstory vegetation and soil patterns. Can. Field-Nat. 96:61-68.

Neudorf, D. L. AND S. G. Sealy. 1994. Sunrise nest attentiveness in cowbird hosts. Condor 96:162169.

OrtegA, C. P. 1998. Cowbirds and other brood parasites. Univ. of Arizona Press, Tucson.

Ortega, C. P. And A. Cruz. 1991. A comparative study of cowbird parasitism in Yellow-headed Blackbirds and Red-winged Blackbirds. Auk 108: 16-24.

Ortega, C. P., J. C. Ortega, and A. Cruz. 1994. Use of artificial Brown-headed Cowbird eggs as a potential management tool in deterring parasitism. J. Wildl. Manage. 58:488-492.

PeCK, G. K. AND R. D. JAMES. 1987. Breeding birds of Ontario: Nidiology and distribution. Vol. 2: passerines. Royal Ontario Museum, Toronto, Ontario, Canada. 
PEER, B. D. 1998. An experimental investigation of egg rejection behavior in the grackles (Quiscalus). Ph.D. thesis, Univ. of Manitoba, Winnipeg.

Peer, B. D. And E. K. Bollinger. 1997a. Explanations for the infrequent cowbird parasitism on Common Grackles. Condor 99:151-161.

Peer, B. D. And E. K. Bollinger. 1997b. Common Grackle (Quiscalus quiscula). In The birds of North America, no. 271 (A. Poole and F. Gill, Eds.). The Academy of Natural Sciences, Philadelphia, Pennsylvania; the American Ornithologists' Union, Washington, D.C.

Peer, B. D., S. K. Robinson, and J. R. Herkert. 2000. Egg rejection by cowbird hosts in grasslands. Auk 117:892-901.

Price, J., S. Droege, AND A. Price. 1995. The summer atlas of North American birds. Academic Press, New York.
Robinson, S. K., S. I. Rothstein, M. C. BRittingham, L. J. Petit, AND J. A. Grzybowski. 1995. Ecology and behavior of cowbirds and their impact on host populations. Pp. 428-460 in Ecology and management of neotropical birds (T. E. Martin and D. M. Finch, Eds.). Oxford Univ. Press, New York.

Rothstein, S. I. 1975. An experimental and teleonomic investigation of avian brood parasitism. Condor 77:250-271.

Rothstein, S. I. 1976. Cowbird parasitism of the Cedar Waxwing and its evolutionary implications. Auk 93:498-509.

Sealy, S. G., D. L. Neudorf, K. A. Hobson, and S. A. GILL. 1998. Nest defense by potential hosts of the Brown-headed Cowbird; methodological approaches, benefits of defense, and coevolution. Pp. 194-211 in Parasitic birds and their hosts: studies in coevolution ( $\mathrm{S}$. I. Rothstein and S. K. Robinson, Eds.). Oxford Univ. Press, New York. 